\title{
Teacher's Directive Speech Acts at Kindergarten School
}

\author{
Kharisma Puspita Sari \\ Universitas Islam Negeri Walisongo \\ elasha.puspita3@gmail.com
}

\begin{abstract}
The research is field research with descriptive qualitative research. The research aims to determine and investigate the teacher's directive speech acts at kindergarten school. The research investigates a teacher in a day of teachinglearning activity at kindergartenschool. Deeply, the research investigates a whole sequence of activity in the class. Actually, there are 6 sessions of the learning activity determined such as; 1) forming in line, 2) circle time, 3) praying up, 4) learning activity, 5) take a rest, 6) learning evaluation and review, 7) praying up, 8) singing a song, 9) closing session. From this sequence of activities, there are three types of directive speech acts which is often used by teacher at certain kindergarten school like requests, requirements, and questions. Specifically, there are several types of directive speech acts in details used by the teacher such as asking, interrogating, inquiring, invite, command, order, hope, suggest, prohibit, advice, and others.
\end{abstract}

\section{ARTICLE HISTORY}

Received 25 June 2018

Accepted 16 August 2018

KEYWORDS

Speech

acts;illocutionaryacts; directiv espeechacts

\section{Introduction}

Language is the important part for human's life. By looking the scope, language is commonly divided into two kinds of study; macrolinguistics and microlinguistics. Microlinguistics is study about language systems abstractly without regard with meaning or notional content of expression. The examples of the branch are syntax, morphology, phonology, and phonotactics. On the other hand, macrolinguistics is study about language system that broader context than microlinguistics. Macrolinguistics concerns with not only structural language study but also how meaning influences the language and what things occur as psychologically factors, domain language, and setting.

In this case, the paper would investigate macrolinguistics especially pragmatics as core of investigation. The paper would investigate pragmatics as the study of the expression of relative distance in contextual meaning (George Yule 1996: 3). The paper would investigate the interpretation of meaning from people in a particular context and how the context influences what is said. Besides, for conducting the notion, automatically there are also other factors supporting the notion like physical, social, and conceptual. The mind concept is investigating the main core of language use and any implications among the speakers and any people surround them. 
Continuing previous explanation, the paper would investigate especially teacher's utterances in teaching learning activity. Dealing with the concept of applied linguistics. Deeply, for applied linguistics is included in the first task of educational system (Bernard Spolsky 1998: 74). The related condition is about formal educational system which becomes national language standard which is applied formally. However, in Indonesia, there is common foreign language as English in teaching learning activity. The pattern of communication belongs to commonly the teacher and the students in a formal situation like a class.

Based on the notion above, the paper would investigate any facts and phenomena occured in the situation related to pragmatics area. The relationship built between the teacher as conductor in a class and the students would tend to be a simultaneously activity. By specifying the scope of investigation, the paper chooses related approach as speech act in pragmatics as core study. Consequences, in order to get exhausted result, the directive area of speech act is choosen as main discussion. The teacher's directive speech acts are choosen as object of investigation. The object of the investigation is the teaching learning activity namely the turn taking among the teacher and the students in kindergarten school.

\section{Speech Act of Pragmatics Context}

As the previous section talked, language reveals as important aspect for human being. It is needed as supporting way between participants in a communication. In a pattern of communication, based on Hymes'theory (cf Hymes 1972) commonly there are three unit of analysis; 1) situation, 2) event, 3) act (Saville \& Troike. These elements as basic aspect in interaction between the speaker and the listener or among the partners of communicative act. The core investigation of the paper is about the communicative act. The main theory about communicative act as a single interaction as communication function which is consisted in a several types like referential statement, a request, a command, or maybe as formed in a verbal or nonverbal communication (Saville \&Troike 2003: 24).

Continuing the notion, based on pragmatics context, the communication also determined in a pattern of managing utterances. According to the pragmatics context, utterance needs to set in a good design among semantics and pragmatics context (Geis 1995: 217). In a set of communication, utterance shaped into a design consists of many factors like transactional and interactional features whether combined also with grammatical features, semantics and pragmatics items. The reason is in a good interactional activity, there are several factors in a term features needed like sematincs, pragmatics, syntax, and other elements.

Another claim comes from Levinson that told linguistics pragmatics in a set of a speech act. The linguist explained that speech act in a term of pragmatics determined some main factors like presupposition and implicature in a particular contex (Levinson 
1983: 226). Nevertheless, from this point of view, speech acts could be verified into a truth conditional meaning based on logical positivism in a set of principle of sentences can be verified or not strickly meaningless.

Furthermore, another opinion is from George Yule claimed that in attempting speech acts, there is a set of mindset about grammatical features and words that shaped in a perform or actions (George Yule 1996: 47). For spesific description about speech acts, there are some types in detail such apology, complaint, compliment, invitation, promise, and request. In a process of a interaction, normally there is relationship between speaker and hearer helped by the circumstances surrounding the utterances. For examples about the notion could be described as like that:

The context: a boss has a great deal of power then the boss's utterance of the expression: "You're tired."

\section{Illocutionary Act}

In a communicative purpose, there is a dimension named illucotinary act. Deeply, illucotionary act is a performed via communicative force of the utterance (George Yule 1996: 48). In details, the notion could be stated as the purposes in the communication such as making a statement, an offer, an explanation, of other communicative purposes. Illucotionary act also divided from illucotionaryintens the means or the purposes in a communication (cf Austin1962). According to the Austin theory, commonly there are four types of illucotionary acts in details; 1) constantives, 2) directives, 3) acknowledgements, 4) commisives (cf Austin 1962; Abd. Syukur Ibrahim 1993: 16). First, constantives explained as the utterance of expression with a specific purpose. Second is directives, told that the purpose is asking the addressee to do something or attempts by the speaker to get the addressee to do something. Third is commisives has the purpose to commit the speaker to some future course of actions. Last is acknowledgement about the expressions of routine activities.

Furthermore, another linguist as Searle stated as detail dimensions of illucotionary act as twelve dimensions or variations attached follows (John Searle 1979:6):

1. Different in the points (the purpose) of the (or types) of speech act

The purpose is an order could be specified by saying that it is attempt to get the hearer to do something.

2. Differences in the direction of fit between words and the world.

There are several categories such as promises, requests, commands, and vows.

3. Differences in expressed psychological states

In general, in the performance of any illocutionary act with a propositional content, the speaker expresses some attitude, state, etc., to that 
propositional content. Notice that this holds even if he is insincere, even if he does not have the belief, desire, intention, regret or pleasure which he expresses, he nonetheless expresses a belief, desire, intention, regret or pleasure in the performance of the speech act.

4. Differences in the force or strength with which the illucotionary point is presented

The certain aspect could be illustrated as stated for example both, "I suggest we go to the movies" and "I insist that we go to the movies" have the same illocutionary point, but it is presented with different strengths.

5. Differences in the status or position of the speaker and hearer as these bear on the illucotionary force of the utterance

If the general asks the private to clean up the room, that is in all likelihood a command or an order. If the private asks the general to clean up the room, that is likely to be a suggestion or proposal or request but not an order or command.

6. Differences in the way the utterance relates to the interesta of the speaker and hearer

As illustration for certain aspects, for example, the differences between boasts and laments, between congratulations and condolences.

7. Differences in relations to the rest of the discourse

Some performative expressions serve to relate the utterance to the rest of the discourse (and also to the surrounding context). For example., "I reply", "I deduce", "I conclude", and "I object". These expressions serve to relate utterances to other utterances and to the surrounding context. Besides, there are another several expressions like "however", "moreover", "therefore", etc.

8. Differeneces in propositional content that are determined ny illucotionary force indicating devices

The differences, for example, between a report and a prediction involve the fact that a prediction must be about the future whereas a report can be about the past or present. These differences correspond to differences in propositional content conditions as explained in Speech Acts.

9. Differences between those acts that must always be speech acts, and those that can be, but need not be performed as speech acts.

The expressions attached such as "I estimate", "I diagnose", "I conclude", etc. All of the examples have same term of purpose among; estimate, diagnose, and conclude. In these cases, no speech act, not even in internal speech acts, not in necessary.

10. Differencesbetween those acts that require extra-linguistic institutions for their performance and those that do not 
There are a large number of illocutionary acts that require an extralinguistic institution, and generally, a special position by the speaker and the hearer within that institution in order for the act to be performed.

11. Differencesbetween those acts where the corresponding illocutionary verb has a performative use and those where it does not.

In the case, most illocutionary verbs have performative uses - e.g. "state", "promise", "order", "conclude". But one cannot perform acts of, e.g., boasting or threatening, by saying "I hereby boast", or "I hereby threaten". Not all illocutionary verbs are performative verbs.

12. Differences in the style of performance in the illocutionary acts

Some illocutionary verbs serve to mark what we might call the special style in which an illocutionary act is performed. Thus, the difference between, for example, announcing and confiding need not involve any difference in illocutionary point or propositional content but only in the style of performance of the illocutionary act.

\section{Directive Speech Acts}

According to the function of speech act, commonly there are two types of speech acts: 1) direct speech act, 2) indirect speech act (George Yule 1996: 54). By determining the theory, there are three types of basic sentences. Therefore, there is a close relationship among the three concepts as; 1) structural forms; declarative, interrogative, imperative or 2) communicative functions; statement, question, command or request.

Continuing the notions, there is a statement from George Yule claimed that there are five types of functions performed by speech acts stated follows (George Yule 1996: 52):

1. Declarations

Types of speech act that change the world via utterance.

2. Representatives

The representative's speech acts as kinds of speech act that state what speaker believes to be the case or not. For example as statements of fact, assertions, conclusions, and descriptions.

3. Expressive

The speech acts described the state what the speaker feels

4. Directives

The types of speech acts claimed that the speakers use to get someone else to do something. The types reveal as commands, orders, requests, and suggestions.

5. Commissives 
Commissives as speech acts that speaker use to commit themselves in other functions.

Besides, as the core point of determination, the directive speech acts are chosen. As the previous explained that directives speech as imperative to someone else gets to do something. Deeply, diretcive speech acts could be spesified as some types of speech act like attached follows (Abd. Syukur Ibrahim 1993: 27):

a. Requestives

The illustration as the speaker asks the addressee to do something. In details, speech acts could be spesified as the term of "asking", "hope", "invite", "suggest", "pray", etc.

b. Questions

In the description, the addresse ask the speaker about something. Genuinely, there are several types of question stated as "asking," "inquiring," and "interrogating".

c. Requirements

Specifically, in term of requirements, the speaker and the addressee, could do some interaction like order, command, manage, dictate, direct, purpose, aim, and others.

d. Prohibitives

In utterance or producing speech, the speaker prohibits the addressee to do something so that there are two commonly conclude as prohibitives act like prohibit and limit.

e. Permisives

In details, the permissive as the utterance could be specified as permitting, giving competence, giving authority, forgiving, giving license, and others.

f. Advisories

There are several types of advisories speech acts like advising, counseling, suggesting, warning, and others.

\section{Research Method}

a. Research Subject

The subject of the research is teacher's directive speech acts at a kindergarten school (PAUD Aisyiyah NABILA Sampangan).

b. Research Model and Design

The design of the research is field research under specific role investigation. The research is included descriptive qualitative research with certain analysis. The result of the analysis is qualitative so that the paper would investigate the result of 
the analysis by attaching some evidence like as data of description about the teacher's directive speech acts in the class. This opinion is in line with Arikunto statement that qualitative result investigates any result in data description without explores numberic data in details (Arikunto 2006: 239). In details, the instrument used for the research is an only single instrument as classroom observation to investigate the teaching-learning activity in the class by determining the directive speech acts occurred by the teacher.

c. Research Procedure

Research procedure is designed as simple steps like such as follows:

1. Determining and deciding the choosen subject of the research

2. Observing the teaching-learning activity in order to get data as directive speech acts occurring from the teacher as the center of learning and the very young learners.

3. Collecting the data in the form of conversation among the teacher and the learners with certain steps; observation, note taking and recording.

4. Analyze the data with the appropriate approach.

5. Taking the conclusion.

6. Get the final result.

d. The technique of Data Analysis

The data collected would be analyzed as a specific conversational organization. The organization of directive speech acts taken from the teacher in the teaching-learning activity; the organization consists of several types such as; requests, questions, requirements, prohibitives, permissive, and advisories.

\section{Findingsand Discussion}

\section{Finding Data}

The sequences activities taken from teaching learning from kindergarten school stated such as follows, the taecher says some utterance attached such as:

a. Forming in line

Teacher:

- Collect your body students!

- Move up your heads!

- Move your hands!

- Let's jump!

- Let's walk!

- Let's sing together!

b. Circle time

In the beginning, before the lesson has ready started, there are two activities held in the class; circle time and praying up. These activities are 
conducting as warming up to build learners' motivation before the lesson has already started. The utterances taken from the teacher are:

- Please enter the class one by one

- (by singing) Make a circle Make a circle with me! With me make a circle make a circle!

- Lift up your foot for 5 seconds!

- Lets jump! Hup Hup Hup

- Sit down together, please!

c. Praying up

- Up your hands!

- Lets read bismillah together

- Let's recite some short verses of Holy Qur'an

d. Learning activity

- Oke students, pay attention, please!

- Listen to me!

- Look at the picture! (shows the picture of fruit)

- Mention the name of pictures!

What is the name of the pictures?

- Mention the color of pictures!

What is the color of the pictures?

- How is taste? (asking the fruit's taste)

e. Take a rest/ eating together

- Please arrange the toys in neat!

- Let's pray before having a rest!

- Wash your hands!

- Do not litter!

- You are allowed to play out of the door

f. Learning evaluation and review

- How is your feeling after learning?

- How is our learning today?

- Tell me what you have learned today!

g. Praying up

- Up your hands!

- (Reciting some short verses of holly Qur'an)

- Please read hamdallah together!

- You should wear the blue uniform tomorrow

- You should go to school on time

h. Singing a song

Let's sing some songs (sayonara, mari pulang, di hati ini ada doa)

i. Lesson has been finished 
- Please go out of the class in neat!

- Please be careful on the way!

- Discussion

- Based on underlying theory, the directive speech acts taken from the teacher could be determined such as follows:

1. Requestives

*) Forming in line:

- Lets jump! (invite)

- Let's walk! (invite)

- Let's sing together! (invite)

*) Circle time

- Lets jump! Hup Hup Hup (invite)

- Sit down together please! (hope)

*) Take a rest

- Please arrange the toys in neat! (hope)

- Let's pray before having a rest! (hope)

- Wash your hands! (asking)

*) Praying up

- Up your hands! (asking)

- (Reciting some short verses of holly Qur'an) (hope)

- Please read hamdallah together! (invite)

*) Singing a song

Let's sing some songs (sayonara, mari pulang, di hati ini ada doa) (hope)

*) Ending of the session

- Please go out of the class in neat! (hope)

- Please be careful on the way! (hope)

2. Questions

*) Learning activity

- Look at the picture! (shows the picture of fruit) (asking)

- Mention the name of pictures! (interrogating)

What is the name of the pictures? (interrogating)

- Mention the color of pictures! (interrogating)

What is the color of the pictures? (interrogating)

- How is taste? (asking the fruit's taste) (interrogating)

*) Learning evaluation and review

- How is your feeling after learning? (inquiring)

- How is our learning today? (inquiring)

- Tell me what you have learned today! (inquiring)

3. Requirements

*) Forming in line session

- Collect your body students! (command) 
- Move up your heads! (command)

- Move your hands! (command)

*) Circle time session

- Please enter the class one by one (order)

- (by singing) Make a circle Make a circle with me! (order)

With me make a circle make a circle! (order)

- Lift up your foot for 5 seconds! (command)

*) Learning activities

- Oke students, pay attention please! (command)

- Listen to me! (command)

4. Prohibitives

- Do not litter! (prohibit)

5. Permissions

You are allowed to play out of the door. (permitting)

6. Advisories

- You should wear a blue uniform tomorrow. (advice)

- You should go to school on time. (advice)

\section{Conclusion}

From any explanation and result of the analysis above, there are several conclusion attached follows:

1. There are commonly six types of teacher's directive speech acts at kindergarten school; 1) requestives, 2) requirements, 3) questions, 4) prohibitives, 5) permissive, 6) advisories.

2. There are three types of directive speech acts are often used at specific kindergarten school; 1) requirements, 2) questions, 3) requests.

3. The directive speech acts of requirements such as; commands, order, manage and dictate.

4. The directive speech acts of questions attached such as; asking and interrogating and inquiring

5. The directive speech acts of requests such as; asking and invite, and hope. 


\section{References}

Arikunto, Suharsimi. (2006). Prosedur Penelitian Suatu Pendekatan Praktik. Jakarta: Rineka Cipta.

Brown, Gillian. (1995). Speakers, Listeners, and Communication. Great Britain: Cambridge University Press.

Geis, Michael. (1995). Speech Acts and Conversational Interaction. United States of America: Cambridge University Press.

Levinson, Stephen C. (1983). Pragmatics. United States of America: Cambridge University Press.

Searle, John R. (1979). Expression and Meaning: Studies in The Theory of Speech Acts. United States of America: Cambridge University Press.

Syukur Ibrahim, Abd. (1993). Kajian Tindak Tutur. Surabaya: Usaha Nasional.

Yule, George. (1996). Pragmatics. United Kingdom: Oxford University Press. 